TAPROBANICA, ISSN 1800-427X. December, 2013. Vol. 05, No. 02: pp. 111-119, 2 pls. (C) Taprobanica Private Limited, 146, Kendalanda, Homagama, Sri Lanka.

http://www.sljol.info/index.php/tapro

\title{
IMPACT OF VEHICULAR TRAFFIC ON HERPETOFAUNAL MORTALITY IN A SAVANNAH FOREST, EASTERN SRI LANKA
}

D. M. S. Suranjan Karunarathna ${ }^{1}$, Sujan M. Henkanaththegedara ${ }^{2}$, A. A. Thasun Amarasinghe ${ }^{3}$ and Anslem de Silva ${ }^{4}$

\footnotetext{
${ }^{1}$ The Young Zoologists' Association, Department of National Zoological Gardens, Dehiwala 10350, Sri Lanka

${ }^{2}$ Biological Sciences, 218 Stevens Hall, North Dakota State University, Fargo, ND 58105, USA

${ }^{3}$ Taprobanica, Perigi RT02/RW06 No. 63, Parigi Baru, Pondok Aren 15228, Tangerang Selatan, Indonesia

${ }^{4}$ Amphibia and Reptile Research Organization of Sri Lanka, 15/1, Dolosbage Road, Gampola, Sri Lanka

E-mails: dmsameera@gmail.com ${ }^{1}$, thasun.taprobanica@gmail.com ${ }^{3}$
}

\begin{abstract}
Mortality of wildlife due to vehicular traffic is among the direct impacts when natural habitats are dissected with roads. This study presents the herpetofaunal mortality on a $3 \mathrm{~km}$ stretch of a highway crossing Nilgala Forest Area (NFA), a savanna dominated forest in Nilgala, eastern Sri Lanka. A total of 72 species of herpetofauna including 53 reptiles and 19 amphibians were recorded as road kills of which 19 species $(26.3 \%)$ are endemic to Sri Lanka and 22 species $(30.5 \%)$ are threatened nationally. A total of 552 road killed individuals $(23.6 \%$ of tetrapod reptiles, $40.2 \%$ of serpentoid reptiles and $36.2 \%$ amphibians) were recorded over 48 days.
\end{abstract}

Key words: Road kills, reptiles, amphibians, threats, human impact, conservation

\section{Introduction}

Roads of all kinds have several broad ecological effects for plants and animals. These ecological effects include modification of animal behavior, alteration of the physical and chemical environment, spread of exotic species, and increased use of areas by humans as well as increased mortality from road construction and collision with vehicles (Trombulak \& Frissell, 1999). The negative impact of roads on wildlife has dramatically amplified with the increased networks of roads throughout the world
(Vijayakumara et al., 2001). This concern is becoming evident with the increasing amount of literature dealing with the ecological effects of roads and traffic (Eberhardt et al., 2013; Hels \& Buchwald, 2001; Bhupathy et al., 2009). The impact of road traffic mortality of the herpetofauna have been well reported from India (e.g. Arijit et al., 2012; Baskaran \& Boominathan, 2010; Bhupathy et al., 2009; Das et al., 2007; Deepak \& Riddhika, 2009; Gopi Sundar, 2004; Gokula, 1997; Selvan, 2011; 
Selvan et al., 2012; Seshadri et al., 2009; Vijayakumara et al., 2001). However, only two studies (Amarakoon et al., 2010 and Maduwage et al., 2003) from Sri Lanka reports in appreciable details on the subject.

Not all species and ecosystems are equally affected by roads, but overall the presence of roads is highly correlated with changes in species composition and population sizes (Forman \& Alexandra, 1998; Trombulak \& Frissell, 1999). When a previously continuous habitat is fragmented, for instance by a road, the potential for dispersal and colonization is often reduced (Andrén, 1994; Vos \& Chardon, 1998). The presence of roads can cause a wide array of cascading events from direct mortality due to vehicular traffic to the reduction of gene flow between mobile species which leads to drift and the loss of genetic diversity (Marsh et al., 2007; Strasburg, 2006). Herpetofaunal species frequent highways not only to cross the fragmented habitat, but they also use roads as an open area to ambush prey, as well as use the road surface for thermal regulation (Bambaradeniya et al., 2001; Karunarathna \& Karunarathna, 2005). In the case of amphibians, they are more vulnerable to highway mortalities due to comparatively slow movements while crossing the roads, but the effects get compounded due to increased mobility during rainy periods and mass reproductive migrations (Trombulak \& Frissell, 1999; Vijayakumara et al., 2001).

de Silva et al. (2004) reported 11 species of amphibians and 38 species of reptiles in the NFA. However recent surveys (Karunarathna \& Amarasinghe, 2011; Karunarathna et al., 2008) showed that the herpetofaunal diversity is much greater with 70 (additional 10 unidentified species) species of reptiles and 22 species of amphibians in the Nilgala forest area (NFA). The rich herpetofaunal diversity in the area is at risk due to a series of threats such as habitat loss, fragmentation and alteration. Furthermore at a local scale, deliberate killing due to fear (especially snakes), collecting for food and medicines as well as collecting for the pet trade are also considerable threats. Herpetofaunal mortality due to vehicular traffic on roads and highways is considered a significant threat to species inhabiting forested areas adjoining roads (Das \& de Silva, 2005; Karunarathna \& Amarasinghe, 2011). In Sri Lanka, a report on the Horton Plains National Park (de Silva, 1999) included a brief account of road traffic mortality of reptiles and this initial study was followed by Bambaradeniya et al. (2001), de Silva (2001), Maduwage et al. (2003), Rodrigo et al. (2003), and Amarakoon et al. (2010). According to studies which were carried out along a $2.25 \mathrm{~km}$ stretch of the DolosbageGampola road, it was reported that a total of 44 reptiles consisting of 15 species and, four amphibians consisting of 2 species were killed by vehicles within two days (de Silva, 2006). A study carried out in the NFA reported that 9 individual reptiles (from 6 species) and 5 individual amphibians (from 1 species) were road-kills during 36 days (de Silva et al., 2004) However, there are undocumented observations that suggest a significant number of reptiles and amphibians are run over daily and killed by road traffic in the NFA. Here we report the findings of a two-year study of herpetological mortality on a $3 \mathrm{~km}$ stretch of a road crossing a savannahdominated forest in eastern Sri Lanka.

\section{Materials and Methods}

Study Area: Nilgala Forest Area (NFA) is a savanna dominated forest approximately 12,432 ha in size, situated in the lower Uva Province, Monaragala District in the eastern part of Sri Lanka (Fig. 1). The NFA lies between $7^{\circ} 08^{\prime}-7^{\circ} 14^{\prime} \mathrm{N}$ and $81^{\circ} 16^{\prime}-81^{\circ} 20^{\prime} \mathrm{E}$, and is a protected forest area under the Forest Department (de Silva et al., 2004; Karunarathna \& Amarasinghe, 2011). The mean annual rainfall varies between 1500 $2000 \mathrm{~mm}$, received mainly during the north-east monsoon (October- January) (de Silva et al., 2004) while the mean annual temperature of the area is $28-31^{\circ} \mathrm{C}$ (Karunarathna \& Amarasinghe, 2011; Somasekaram et al., 1997). The major vegetation of NFA can be classified as lowland tropical dry mixed evergreen forest (Gunatileke \& Gunatileke, 1990). Furthermore, four subvegetation categories were identified within NFA limits; savannah grasslands, monsoon forests, anthropogenically modified vegetation (e.g. croplands and home gardens) and degraded vegetation with predominantly thorny weeds (de Silva et al., 2004). Road kills were recorded on a $3 \mathrm{~km}$ stretch of the BibileAmpara road from Pitakumbura junction to Maldam-ambae junction during the years 2004-2005 in NFA. 

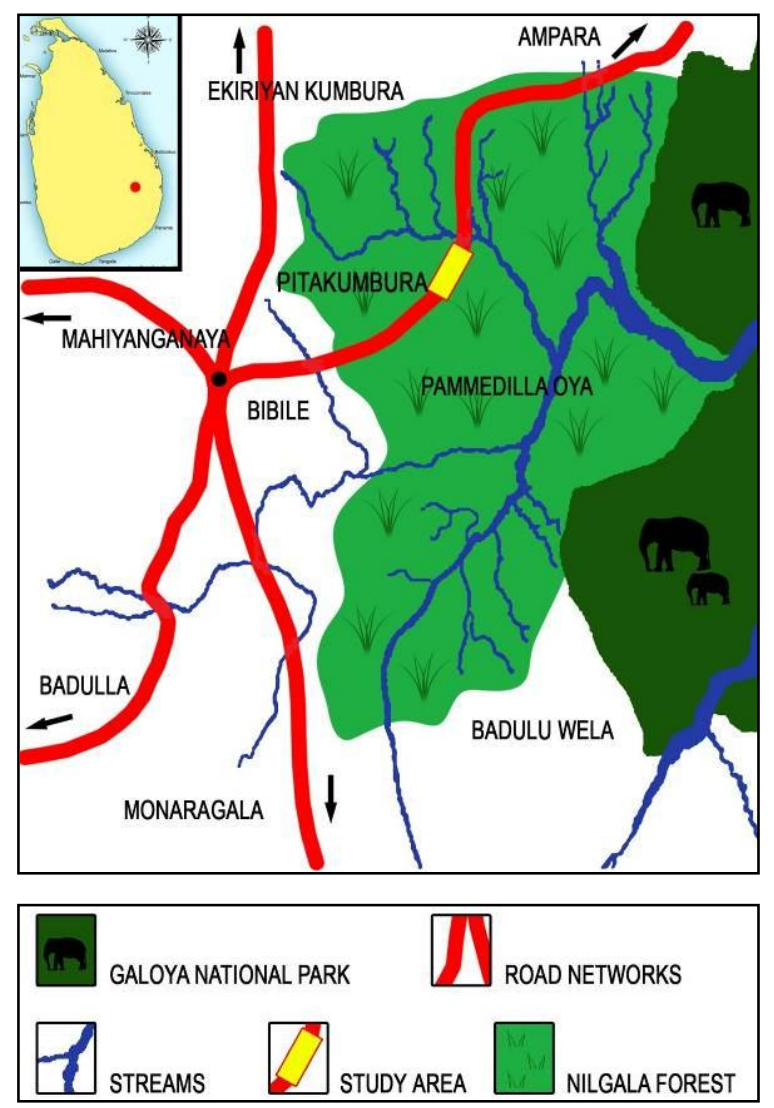

Figure 1: Map of the study area (NFA)

Sampling and Analysis: The study was conducted from January 2004 to December 2005 over 48 days, two days per month. Observations were made during the mornings (approximately 07:00-09:00 h) and early evenings (approximately 16:00-18:00 $\mathrm{h}$ ) on the same day by walking through the selected stretch of the road. Weather conditions were noted down as wet, if there was a rain or drizzle or dry if no precipitation or bright sunlight at the time of the survey. The number of vehicles passing was counted while walking the $3 \mathrm{~km}$ stretch. All road killed specimens were examined and identified to species level but not collected. However, they were removed from the road to avoid multiple counts of the same kill. Additionally, the road side microhabitats on the road segment were recorded according to four categories (savannah grasslands, home gardens, monsoon forests and wetlands) to assess any effects of the habitat on mortality. The relative index of each microhabitat type is almost the same and it is 25\%. Most road killed amphibians were damaged extensively beyond identification of species. Thus we did not include those species/individuals in this analysis, thus our result is an underestimation for this group. The specimens were identified by using field guides and identification keys (Das \& de Silva, 2005; Dutta \& ManamendraArachchi, 1996; Deraniyagala, 1953, 1955; de Silva, 1990, De Silva, 1980; Manamendraarachchi, 1997; Manamendra-Arachchi \& Pethiyagoda, 2005; Meegaskumbura \& Manamendra-Arachchi, 2005.) during the study, and the species described after 2005 identified based on the field notes and morphological characters recorded during the study, and identification keys (ManamendraArachchi \& Pethiyagoda, 2006; Somaweera \& Somaweera, 2009).

We employed MINITAB 14 (Minitab Inc., 2003) for statistical analysis of data. Monthly total mortality, relative mortality and annual mortality rates were assessed for different families of reptiles and amphibians for 2004 and 2005. The annual herpetofaunal mortality due to vehicular traffic per kilometer stretch of the road (total mortality $/ \mathrm{km} /$ year) was calculated as an index to estimate the impact of vehicular traffic on herpetofaunal mortality. The threat status of the road traffic killed reptiles was listed according to MOE (2012). To understand the diversity of herpetofauna of the road-kills, we employed several indices to assess species richness, dominance and heterogeneity (Magurran, 1988). Since herpetofauna of the general region is more active during wet season (personal observations), we expected increased mortality rates during the wet season. We hypothesized that any variation in mortality is a function of rainfall because; precipitation could motivate movements of organisms (Dodd \& Cade, 1998; Madsen et al., 2006) and no apparent increase of vehicular traffic was observed in a given season in NFA. Rainfall data were obtained for the nearest weather station (Welipitiya Coconut Plantation, Badulla of National Meteorological Department, Sri Lanka). We ran Pearson's correlation between total monthly mortality and total monthly rainfall separately for reptiles and amphibians for both years to see any relationships. Further we assessed total mortality of herpetofauna according to major adjacent habitat type to understand the effect of habitat type on mortality of both reptiles and amphibians. One-way ANOVA test was used for pooled data to analyze significant differences between mean mortalities of four different habitat types following pair-wise 
comparisons using Fisher's LSD test, separately for reptiles and amphibians.

\section{Results}

In total, 92 herp species $(33.45 \%$ of island total) were recorded in NFA and 72 species (78.26\% of NFA total) were observed as roadkills (Appendix 1, plates 1-2). Among road kills, 22 species (six amphibians and 16 reptiles) are endemic to Sri Lanka and 17 (four amphibians and 13 reptiles) have been identified as threatened species (MOE, 2012). Lower numbers of herpetofauna were recorded as road-kills in 2005 compared to 2004. Altogether 53 and 46 reptile species were recorded as road kills respectively in 2004 and 2005. Corresponding amphibian numbers were 19 and 17 for the two years, respectively. Overall for both years, a total of 351 individuals of road killed reptiles belonging to 53 species, 35 genera and 13 families and 201 road killed amphibians represented by 19 species, 13 genera and four families were recorded. The average annual mortality rate for reptiles was $4.51( \pm 1.99) / \mathrm{km} /$ year and $8.33( \pm 3.90) / \mathrm{km} /$ year for amphibians (Fig. 2). 33 snake species (45.8\% of total mortalities) and 20 tetrapod reptile species $(27.8 \%$ of total mortalities) were recorded as road kills in the present study. Out of 22 species of amphibians recorded in NFA, 19 species were recorded in road kills. Nearly $19.02 \% \quad(n=105)$ of total herpetofaunal mortality was represented by endemic species and $21.19 \% \quad(n=117)$ by threatened species. Families such as Elapidae, Viperidae, Agamidae, Gekkonidae and Ranidae were represented by more than $30 \%$ mortality of endemic species due to vehicular traffic. The mortality of threatened species is represented by more than $30 \%$ mortality in Elapidae, Gekkonidae and Agamidae and $100 \%$ in the families Boidae, Cylindrophidae, Crocodylidae, Bataguridae, Testudinidae and Ichthyophiidae. We observed some temporal variations of the herpetofaunal mortality due to vehicular traffic in NFA. The highest mortality recorded for reptiles was 38 mortalities in January 2004, mostly due to mortalities of two aquatic species of checkered keelbacks (Xenochrophis asperrimus \& X. piscator, $82.6 \%$ of total).

In the case of amphibians, Narrow-mouthed frogs (Microhylidae) represented more than half $(51.24 \%)$ of the total number of amphibians recorded, followed by True frogs
(Ranidae) (37.31\%), True toads (Bufonidae) $(10.94 \%)$ and Asiatic tailed caecilians (Ichthyophiidae) (0.50\%). Microhylid frogs represent $51.50 \%$ of all road killed amphibians and $18.66 \%$ of all herpetofauna. Red narrow mouth frog (Microhyla rubra) was the most abundant amphibian $(37.5 \%, n=75)$ among road kills. Highest amphibian mortality was 27 in April 2005 and mostly due to mortalities of Red Narrow Mouth Frog (Microhyla rubra, 81.5\% of total).

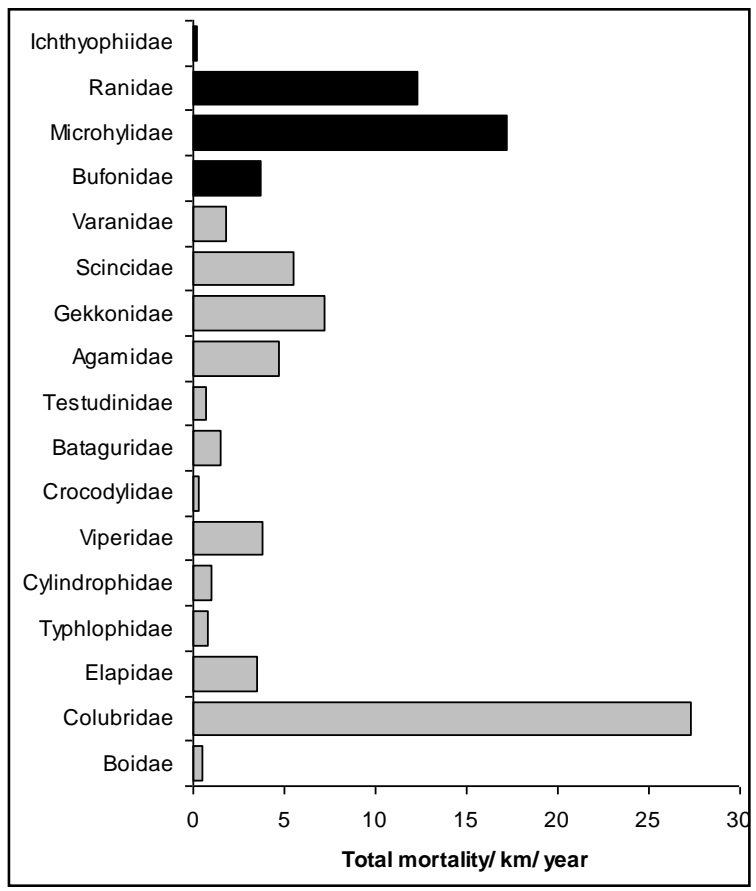

Figure 2: The number of herpetofaunal mortality, per kilometer, per year; amphibian families (black bars) and reptile families (grey bars).

For reptiles, more than $63 \%(n=222)$ of the road kills were snakes. Families included Colubridae $(46.6 \%, n=164)$, Viperidae $(6.5 \%$, $n=23)$, Elapidae $(6.3 \%, n=2)$, Cylindrophidae $(1.7 \%, n=6)$, Typlophidae $(1.4 \%, n=5)$ and Boidae $(0.85 \%, n=3)$. The Buff striped keelback (Amphiesmma stolata) was the most recorded road-kill species among colubrids $(10.4 \%, n=17)$ as well as among snakes $(7.6 \%)$. Two other colubrids, Green vine snake (Ahaetulla nasuta) and Trinket Snake (Coelognathus helena) also showed a considerable mortality with respect to the total reptile mortality $(3.97 \%, n=14$ and $3.69 \%$, $n=13$ respectively). Gekkonids represented, $12.2 \%$ of road kills. The Four-claw gecko (Gehyra multilata) and Kandyan gecko (Hemidactylus depressus) were the most common gekkonids $(2.56 \%, n=9$ each). Two 
endemic species of the family Agamidae were represented in the road kill statistics. The Painted-lip lizard (Calotes ceylonensis) $(n=8)$ and Black kangaroo lizard (Otocryptis nigristigma) $(n=7)$. The Green garden lizard (Calotes calotes) was the most common Agamid in road kills $(2.56 \%, n=9)$. There were fewer road kills in the families Crocodylidae $(n=2)$ and Boidae $(n=3)$ than any other reptile family.

Analysis of diversity parameters of road kills showed a peak in reptile mortality during January-March for both years. There were no significant variations of amphibian mortalities except comparatively low mortality in February 2004 i.e. only two individuals of common house toad (Duttaphrynus melanostictus). Although we expected an increased mortality of organisms with rainfall, there was no significant correlation between total mortality and rainfall for amphibians $\left(\mathrm{F}_{2,21}=1.94 ; \mathrm{P}>0.05\right)$ and reptiles $\left(\mathrm{F}_{2,21}=1.38 ; \mathrm{P}>0.05\right)$ for either years (Fig. 3). There was a significant difference between mean mortalities of reptiles reported in four different microhabitat types $\left(\mathrm{F}_{3,21}=11.31, \mathrm{P}<0.001\right)$, but there was no significant difference for amphibians (Fig. 4).
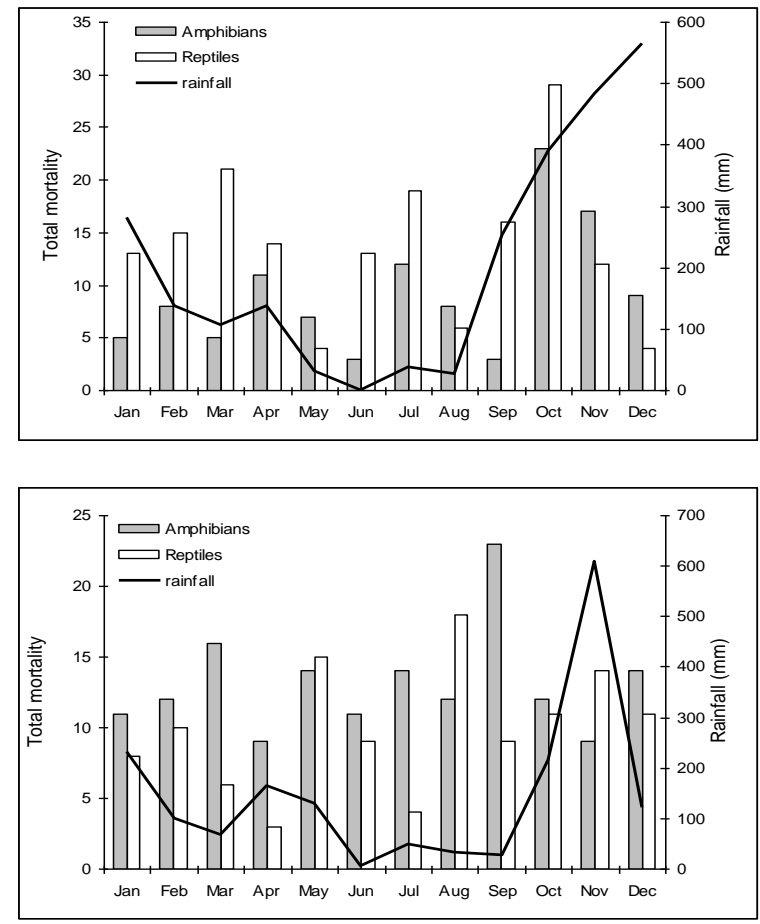

Figure 3: The fluctuations of herpetofaunal mortality and rainfall in 2004 (above), and 2005 (below).

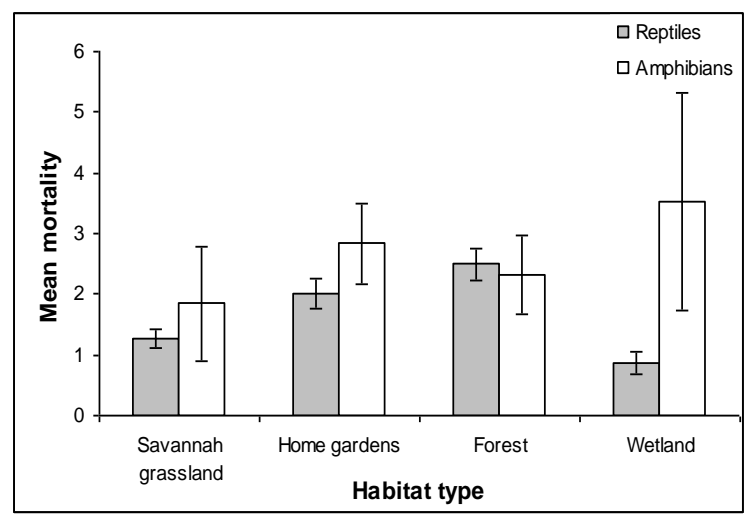

Figure 4: Mean herpetofaunal mortality in four different adjacent habitat types; bars indicate standard error.

The highest number of deaths for any single reptile species recorded was for the Buff striped keelback (Amphiesma stolata) and $47.0 \%$ of their total mortality was from roads adjacent to home gardens. $77.8 \%$ of total mortalities of the Sri Lanka cat snake (Boiga ceylonensis) came from road adjacent to forested areas. The three road-killed specimens of Indian python (Python molurus) were recorded from savanna grassland $(n=2)$ and forested areas $(n=1)$. The highest mortalities of colubrids were reported in forested areas followed by home gardens. The numbers of vehicles were consistent throughout the survey period and mean is 68 $( \pm 5)$ vehicles during morning, and $52( \pm 3)$ during evenings as this area is very rural.

\section{Discussion}

Mortality of wildlife due to vehicles is highly detrimental, especially for species with small and declining populations (Spellerberg, 1998) and in places where species diversity is high (e.g. this study). Previous studies on herpetofaunal mortality on highways of Sri Lanka presented comparatively low mortality rates (Bambaradeniya et al., 2001; de Silva et al., 2004; Rodrigo et al., 2003). A previous study in NFA recorded only one amphibian species and six reptile species in road kills within 36 days (de Silva et al., 2004) compared to significantly higher number of road-killed herpetofaunal species (53 reptiles and 19 amphibians) recorded by present study. This difference may reflect the need for extended effort and prolonged sampling for such a study to understand the total impact.

We observed most amphibians crossing the road after rains even though there is no 
correlation between rainfall and road killed amphibians. Some of them were mating and some were feeding on insects that came out from the soaked earth. The reason for us recording high numbers of microhylid frogs among road kills may be that they are small amphibians which have short limbs and cannot move fast. Most lizards appear to attempt to cross surfaced road less frequently, perhaps due to smaller home ranges (Tatlor \& Goldingay, 2004). Nocturnal reptiles make use of road and road edges in order to aid thermoregulation using residual heat that is absorbed and slowly released by road surface material (Bambaradeniya et al., 2001; Karunarathna \& Karunarathna, 2005). Some reptiles use the loose soil beside roads to lay eggs suggesting that there may be thermal benefits for eggs in these more open and heated places (pers. comm. Ruchira Somaweera, November 2013). Some reptile species that have wide ranges are frequently killed on roads when crossing and basking on roads such as tropical boas and pythons (Langton, 2002). The possible reasons for high rates of snake mortality are fast movements of small tetrapod reptiles compared to coiling behavior of snakes (zero mobility) under vibrations from vehicles, deliberate killing upon sight by drivers due to aggressive attitude towards all snakes (Bambaradeniya et al., 2001). Although we did not assess the abundance of herpetofauna in adjacent habitats, we think that the total mortality of each taxon represents relative abundance of them in different habitats. We also believe this pattern reflects the primary habitat of each herp species.

The existence of a rich herpetofauna in NFA is at risk due to several threats including encroachment and clearance of natural habitats for cultivations, annual man made fires in savannah, extensive use of chemicals for agriculture and mortality due to vehicular traffic. This study reveals that the impact of vehicular traffic on herpetofauna is more severe than the levels recorded previously. Most of the roads around these areas have been widened since 2007 according to the National Road Master Plan of Sri Lanka (RDA, 2007). For example the road B527 where our site is located was classified as a single line road in 2007 (RDA 2007), but is currently a B-class double line road. Additionally many other roads around Bibile and Ampara now are in developing process. Even though the road B527 was not on the proposal to develop, that road will be highly accessed as an alternative road from Bibile to Ampara. The potentially increased traffic resulting from this could lead to more animals being killed. The road network in the country needs to be developed in order to accommodate the increasing demand for transportation; however it is crucial to recognize the potential threats to biodiversity from these developments and utilise proper scientific research in the planning and implementing stages to mitigate the impacts.

\section{Acknowledgements}

We thank John Rudge for reviewing the manuscript. T. Abeywardena, P. Silva, R. Sirimanna, A. Udaykumara, C. Soyasa, T. Pieris, B. Jayaneththi, N. Karunarathna, M. Botejue, M. De Silva, D. Wickramasinghe, A. Kumarasinghe, M. Wickramasinghe (YZA), Samantha, Champika, Indika, Lal, Chaminda, Asanka, Somapala, Kulathunga, Punchibanda, Upananada, Lahiru, Dhanapala, Kasun, Latha, Indra, Manike, Ukkumanika, Thisami, Sumanawathe, Ukkun, Kotagama, Tikiri, and villagers of Pitakumbura are acknowledged for assisting field works and logistic support. Special thanks to A. Wijetunge for statistical data analysis and anonymous reviewers for constructive comments on the manuscript.

\section{Literature cited}

Amarakoon, A. M. R. K., E. S. Nathanael, and A. de Silva, 2010. The pattern of reptiles killed by road traffic on the Anuradhapura-Mihintale Road, Sri Lanka. Lyriocephalus, 7: 81-88.

Andrén, H., 1994. Effects of habitat fragmentation on birds and mammals in landscapes with different proportions of suitable habitat: a review. Oikos, 71: 355-366.

Arijit, P., D. Somenath, and U. S. Roy, 2012. Seasonal diversity and abundance of herpetofauna in and around an industrial city of West Bengal, India. Journal of Applied Sciences in Environmental Sanitation, 7: 281-286.

Bambaradeniya, C. N. B., L. J. M Wickramasingha, V. A. P. Samarawickrama, and L. D. C. B. Kekulandala, 2001. Herpetofaunal Mortality in highways: A case study from Sri Lanka. Proceedings of $4^{\text {th }}$ World Congress of Herpetology, Sri Lanka: 10-11. 
Baskaran, N., and D. Boominathan, 2010. Road kill of animals by highway traffic in the tropical forests of Mudumalai Tiger Reserve, southern India. Journal of Threatened Taxa, 2: 753-759.

Bhupathy, S., G. Srinivas, N. S. Kumar, T. Karthik, and A. Madhivanan, 2009. Herpetofaunal mortality due to vehicular traffic in the Western Ghats, India: a case study. Herpetotropicos, 5: 119-126.

Das, I., and A. de Silva, 2005. Photographic guide to the Snakes and other Reptiles of Sri Lanka. New Holland Publishers Ltd, UK.

Das, A., M. F. Ahmed, B. P. Lahkar, and P. Sharma, 2007. A preliminary report of reptilian mortality on road due to vehicular movement near Kaziranga National Park, Assam, India. Zoos' Print Journal, 22: 2742-2744.

Deepak, R., and V. K. Riddhika, 2009. A report on reptile road-kills in a rural area of Tamil Nadu, India. Cobra, 3: 9-14.

Deraniyagala, P. E. P., 1953. A Colored Atlas of some vertebrates from Ceylon, Tetrapod Reptilia. National Museums of Sri Lanka, Colombo. Sri Lanka.

Deraniyagala, P. E. P., 1955. A Colored Atlas of Some Vertebrates from Ceylon, Serpentoid Reptilia. National Museums of Sri Lanka, Colombo. Sri Lanka.

de Silva, A., 1990. Colour Guide to the snake fauna of Sri Lanka. R \& A Publishing Ltd, UK.

de Silva, A., 1999. The habitat preferences and the status of amphibians and reptiles at Horton Plains National Park. Report, Zoological Survey of Sri Lanka. National Science Foundation, Colombo: 67.

de Silva, A., 2001. The Herpetofauna of Sri Lanka, historical aspects and current status. Ministry of Environment, Sri Lanka.

de Silva, A. 2006. Current status of the Reptiles of Sri Lanka. Pp 134-163. In: C. N. B. Bambaradeniya (Ed.), Fauna of Sri Lanka: Status of Taxonomy, Research and Conservation. IUCN Sri Lanka.

de Silva, A., A. Bauer, C. C. Austin, S. Goonawardena, Z. Howke, V. Vanneck, A. Drion, P. De Silva, B. J. K. Perera, R. L. Jayaratne, and M. M. Goonasekera, 2004. The Diversity of
Nilgala Forest, Sri Lanka, with special reference to its herpetofauna. Lyriocephalus, 5: 164-182.

De Silva, P. H. D. H., 1980. Snakes Fauna of Sri Lanka, with special reference to skull, dentition and venom in snakes. National Museums of Sri Lanka, Colombo, Sri Lanka.

Dodd, C. K., and B. S. Cade, 1998. Movement patterns and the conservation of amphibians breeding in small, temporary wetlands. Conservation Biology, 12: 331-339.

Dutta, S. K., and K. N. Manamendra-Arachchi, 1996. The Amphibian Fauna of Sri Lanka, Wildlife Heritage Trust of Sri Lanka.

Eberhardt, E., S. Mitchell, and L. Fahrig, 2013. Road kill hotspots do not effectively indicate mitigation locations when past road kill has depressed populations. The Journal of Wildlife Management, 77: 1353-1359.

Forman, T. T. R., and L. E. Alexandra, 1998. Roads and their major ecological effects. Annual Review of Ecological System, 29: 207-231.

Gokula, V., 1997. Impact of vehicular traffic on snakes in Mudumalai Wildlife Sanctuary. Cobra, 27: 26

Gopi Sundar, K. S., 2004. Mortality of herpetofauna, Birds and Mammals due to vehicular traffic in Etawah district, Uttrapradesh. India. Journal of the Bombay Natural History Soceity, 103: 392-398.

Gunatileke, I. A. U. N., and C. V. S. Gunatileke, 1990. Distribution of floristic richness and its conservation in Sri Lanka. Conservation Biology, 4: $21-31$.

Hels, T., and E. Buchwald, 2001. The effect of road kills on amphibian populations. Biological Conservation, 99: 331-340.

MOE, 2012. The National Red List 2012 of Sri Lanka; Conservation Status of the Fauna and Flora. Ministry of Environment, Colombo, Sri Lanka.

Karunarathna, D. M. S. S., and A. A. T. Amarasinghe, 2011. A preliminary survey of the reptile fauna in Nilgala forest and its vicinity, Monaragala District, Sri Lanka. Taprobanica, 3: 69-76 
Karunarathna, D. M. S. S., and D. M. G. N. Karunarathna, 2005. An unusual behavior of Otocryptis nigristigma Bahir \& Silva, 2005 (Reptilia: Agamidae) observe at Nilgala forest in Sri Lanka. Sri Lanka Naturalist, 7: 21-22.

Karunarathna, D. M. S. S., U. T. I. Abeywardena, M. D. C. Asela, and L. D. C. B. Kekulandala, 2008. A preliminary survey of the Amphibian fauna in Nilgala Forest area and its vicinity, Sri Lanka. Herpetological Conservation and Biology, 3: 264-272.

Langton, A. E. S., 2002. Measures to protect amphibians and reptiles from road traffic. Pp 223-248. In: Sherwood, B., D. Cutler and J. Burton (Eds.), wildlife and roads, the ecological impact. Imperial College Press, London, UK.

Maduwage, K. P., A. Silva, and S. Batuwita, 2003. Snakes killed on the roads of the gardens of the University of Peradeniya. Loris, 23: 22-24.

Magurran, A. E., 1988. Ecological diversity and its measurement. Chapman \& Hall, London. UK.

Manamendra-Arachchi, K. N., 1997. Gecko! Sri Lanka Nature, 1: 45-55.

Manamendra-Arachchi, K., and R. Pethiyagoda, 2005. The Sri Lankan shrub-frogs of the genus Philautus Gistel, 1848 (Ranidae: Rhacophorinae), with description of 27 new species. Pp. 163-303. In: D. C. J. Yeo, P. K. L. Ng and, R. Pethiyagoda (Eds.), Contributions to biodiversity exploration and research in Sri Lanka. The Raffles Bulletin of Zoology, Supplement 12.

Manamendra-Arachchi, K., and R. Pethiyagoda, 2006. Sri Lankawe Ubhaya jeeween [Amphibians of Sri Lanka]. Wildlife Heritage Trust of Sri Lanka, Colombo, Sri Lanka (Text in Sinhala).

Madsen, T., B. Ujvari, R. Shine, and M. Olsson, 2006. Rain, rats and pythons: climate-driven population dynamics of predators and prey in tropical Australia. Austral Ecology, 31: 30-37.

Marsh, D. M., R. B. Page, T. J. Hanlon, R. Corritone, E. C. Little, D. E. Seifert, and P. R. Cabe, 2007. Effects of roads on patterns of genetic differentiation in red-backed salamanders, Plethodon cinereus. Conservation Gentics, 9: 603-613.

Meegaskumbura, $\mathrm{M}$ and $\mathrm{K}$. ManamendraArachchi, 2005. Description of eight new species of shrub-frogs (Ranidae: Rhacophorinae: Philautus) from Sri Lanka. Pp. 305-338. In: D. C. J. Yeo, P. K. L. Ng and, R. Pethiyagoda (Eds.), Contributions to biodiversity exploration and research in Sri Lanka. The Raffles Bulletin of Zoology, Supplement 12.

Minitab Inc., 2003. MINITAB Statistical Software, Release 14 for Windows, State College, Pennsylvania.

RDA, 2007. National Road Master Plan of Sri Lanka 2007-2017. Road Development Authority, Government of Sri Lanka: 37. Open accessed at http://www.rda.gov.lk/supported/noticeboard/publ ications/nrmp_executiveSummary.pdf

Rodrigo, R. K., V. A. M. P. K. Samarawickrama, N. Perera, M. S. J. Perera, T. N. Peries, and C. N. B. Bambaradeniya, 2003. Herpetofaunal mortality along Tangalle-Ambalantota main road and minor roads in between in the South-East coast of Sri Lanka. Proceedings of. $23^{\text {rd }}$ Annual sessions of the Institute of Biology, Sri Lanka, 23: 13-13.

Selvan, K. M., 2011. Observation of road kills on Kambam-Kumily Road (NH 220) in Tamil Nadu. Zoos' Print, 26: 25-26.

Selvan, K. M., S. Natarajan, and J. Sajan, 2012. Roadkill animals on national highways of Karnataka, India. Journal of Ecology and the Natural Environment, 4: 363-365.

Seshadri, K. S., A. Yadev, and K. V. Gururaja, 2009. Road kills of amphibians in different land use areas from Sharavathi river basin, central Western Ghats India. Journal of Threatened Taxa, 1: 549-552.

Somasekaram, T, M. P. Perera, M. B. G. de Silva, and H. Godellawatta (Eds), 1997. Arjuna's Atlas of Sri Lanka. Arjuna Consulting Company, Sri Lanka.

Somaweera, R. \& Somaweera, N., 2009. Lizards of Sri Lanka: A Colour Guide with Field Keys. Chimaira Publications, Frankfurt.

Spellerberg, I. F., 1998. Ecological effects of roads and traffic, a literature review. Global Ecological and Biogeography Letter, 7: 317-333.

Strasburg, J. L., 2006. Roads and genetic connectivity. Nature, 440: 875-876. 
Trombulak, S. C., and C. A. Frissell, 1999. Review of ecological effects of roads on terrestrial and aquatic communities. Conservation Biology, 14: 18-30.

Vijayakumara, S. P., K. Vasudevan, and N. M. Ishwar, 2001. Herpetofaunal Mortality on Roads in the Anamalai Hills, Southern Western Ghats. Hamadryad, 26: 253-260.
Vos, C. C., and J. P. Chardon, 1998. Effects of Habitat Fragmentation and Road Density on the Distribution Pattern of the Moor Frog Rana arvalis. Journal of Applied Ecology, 35. 44-56.

Appendix 1: List of road killed amphibian and reptile species in NFA, Sri Lanka. EN, endangered; VU, vulnerable; NT, near threatened; LC, least concerned; E, endemic to Sri Lanka (based on MOE, 2012).

\begin{tabular}{|c|c|c|}
\hline \multicolumn{3}{|c|}{ AMPHIBIANS } \\
\hline Family Bufonidae & Family Ranidae & Family Ichthyophiidae \\
\hline Bufo atukoralei $i^{\mathbf{E} / \mathbf{N T}}$ & Hoplobatrachus crassus ${ }^{\mathbf{L C}}$ & Ichchiophis glutinosus $\mathbf{E / V U}$ \\
\hline Bufo melanostictus ${ }^{\mathbf{L C}}$ & Fejervarya limnocharis $\mathbf{L C}$ & \\
\hline & Euphlyctis cyanophlyctis ${ }^{\mathbf{L C}}$ & \\
\hline Family Microhylidae & Euphlyctis hexodactyla ${ }^{\mathbf{L C}}$ & \\
\hline Kaloula taprobanica ${ }^{\mathbf{L C}}$ & Hylarana gracilis $\mathbf{E} / \mathbf{L C}$ & \\
\hline Microhyla ornata ${ }^{\mathbf{L C}}$ & Sphaerotheca breviceps ${ }^{\mathbf{L C}}$ & \\
\hline Microhyla rubra ${ }^{\mathbf{L C}}$ & Sphaerotheca rolendae $\mathbf{L C}$ & \\
\hline Ramanella variegata $^{\mathbf{L C}}$ & Pseudophilautus fergusonianus $\mathbf{E} / \mathbf{V U}$ & \\
\hline Uperodon systoma $^{\mathbf{L C}}$ & Pseudophilautus regius $\mathbf{E} / \mathbf{V U}$ & \\
\hline & Polypedates cruciger $\mathbf{E / L C}$ & \\
\hline & Polypedates maculates ${ }^{\mathbf{L C}}$ & \\
\hline
\end{tabular}

\begin{tabular}{|c|c|}
\hline & REPTILES \\
\hline Family Boidae & Family Elapidae \\
\hline Python molurus ${ }^{\mathbf{L C}}$ & $\begin{array}{l}\text { Bungarus caeruleus } \mathbf{L C} \\
\text { Bungarus ceylonicus }^{\mathbf{E} / \mathbf{V u}}\end{array}$ \\
\hline $\begin{array}{l}\text { Family Colubridae } \\
\text { Ahaetulla nasuta LC }\end{array}$ & $\begin{array}{l}\text { Calliophis melanurus } \\
\text { Naja naja }\end{array}$ \\
\hline
\end{tabular}

Ahaetulla pulverulenta ${ }^{\mathbf{L C}}$

Amphiesma stolata ${ }^{\mathbf{L C}}$

Aspidura brachyorrhos $\mathbf{E} / \mathbf{V U}$

Atretium schistosum $\mathbf{L C}$

Boiga ceylonensis ${ }^{\mathbf{L C}}$

Boiga forsteni ${ }^{\text {NT }}$

Coelognathus helena ${ }^{\mathbf{L C}}$

Dendrelaphis bifrenalis $\mathbf{E} / \mathbf{N T}$

Dendrelaphis tristis $\mathbf{L C}$

Dryocalamus nympha ${ }^{\mathbf{L C}}$

Lycodon aulicus $\mathbf{L C}$

Lycodon osmanhilli ${ }^{\mathbf{E} / \mathbf{L C}}$

Lycodon striatus ${ }^{\mathbf{L C}}$

Macropisthodon plumbicolor ${ }^{\mathrm{NT}}$

Oligodon arnensis $\mathbf{L C}$

Oligodon sublinatus E/LC

Oligodon taeniolatus ${ }^{\mathbf{L C}}$

Ptyas mucosa ${ }^{\mathbf{L C}}$

Sibynophis subpunctata ${ }^{\text {NT }}$

Xenochrophis asperrimus $\mathbf{E} / \mathbf{L C}$

Xenochrophis $_{\text {cf. }}$. piscator ${ }^{\mathbf{E} / \mathbf{L C}}$

Geochelone elegans ${ }^{\mathrm{NT}}$

\section{Family Typhlophidae}

Ramphotyphlops cf. braminus ${ }^{\mathbf{L C}}$

Family Cylindrophidae

Cylindrophis maculata $^{\text {E/NT }}$

Family Viperidae

Daboia russelii ${ }^{\mathbf{L C}}$

Hypnale hypnale ${ }^{\mathbf{L C}}$

Hypnale cf. nepa ${ }^{\mathbf{E} / \mathbf{E N}}$

Trimeresurus trigonocephalus $\mathbf{E} / \mathbf{L C}$

\section{Family Crocodylidae}

Crocodilus palustris ${ }^{\mathrm{NT}}$

Family Bataguridae

Melanochelys trijuga ${ }^{\mathbf{L C}}$

Family Testudinidae
Family Agamidae

Calotes calotes $\mathbf{L C}$

Calotes ceylonensis $\mathbf{E} / \mathbf{N T}$

Calotes versicolor ${ }^{\mathbf{L C}}$

Otocryptis nigristigma $\mathbf{E / L C}$

Family Gekkonidae

Geckoella triedra $\mathbf{E} / \mathbf{V u}$

Gehyra mutilata LC

Hemidactylus parvimaculatus ${ }^{\mathbf{L C}}$

Hemidactylus depressus $\mathbf{E} / \mathbf{L C}$

Hemidactylus frenatus $\mathbf{L C}$

Hemidactylus leschenaultii ${ }^{\mathrm{LC}}$

Hemidactylus lankae $\mathbf{E}^{\mathbf{L} \mathbf{L C}}$

Family Scincidae

Lankascincus fallax $\mathbf{E} / \mathbf{L C}$

Lygosoma punctata ${ }^{\mathbf{L C}}$

Eutropis carinata ${ }^{\mathbf{L C}}$

Eutropis macularia ${ }^{\mathbf{L C}}$

Family Varanidae

Varanus bengalensis ${ }^{\mathbf{L C}}$

Varanus salvator ${ }^{\mathbf{L C}}$ 


\section{PLATE 1}

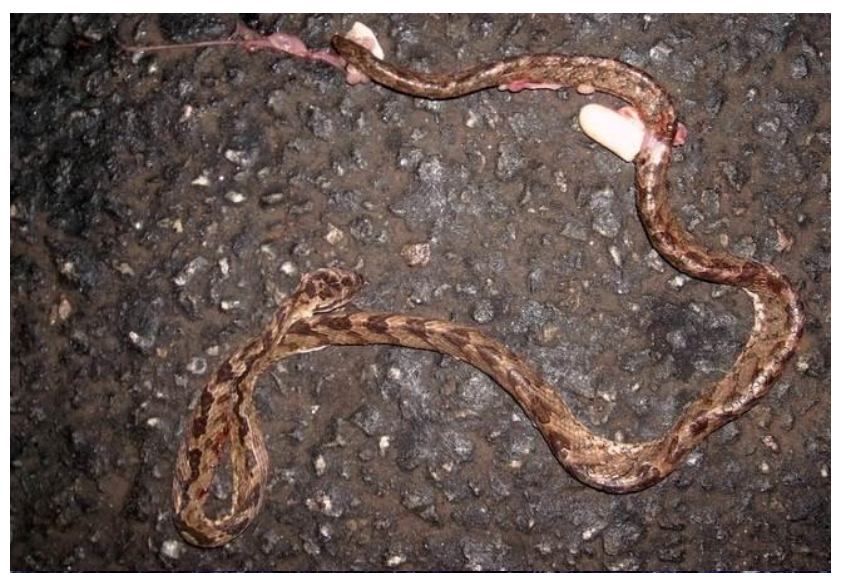

Figure 5: Boiga ceylonensis

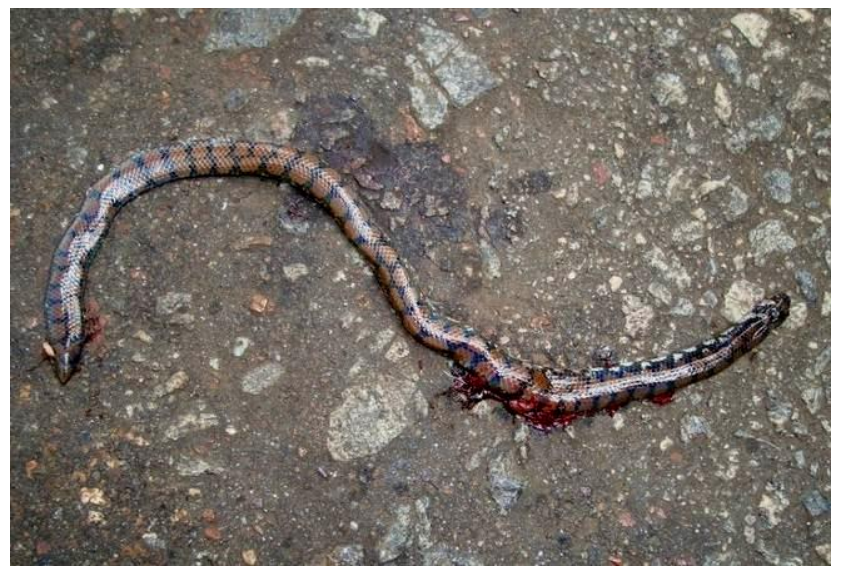

Figure 7: Cylindrophis maculata

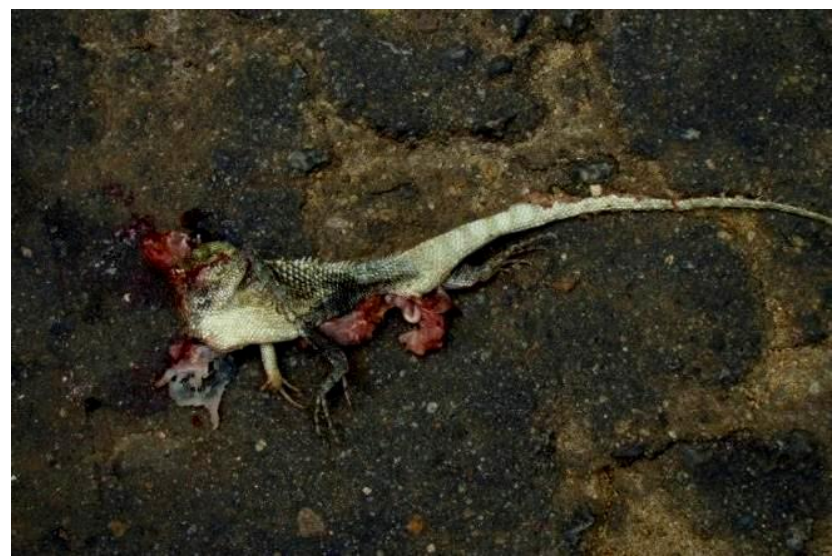

Figure 9: Calotes versicolor

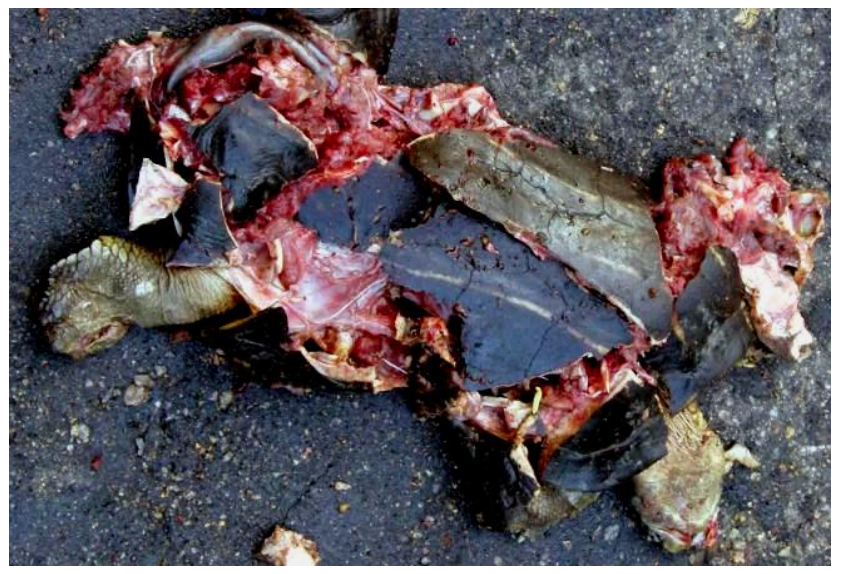

Figure 11: Melanochelys trijuga

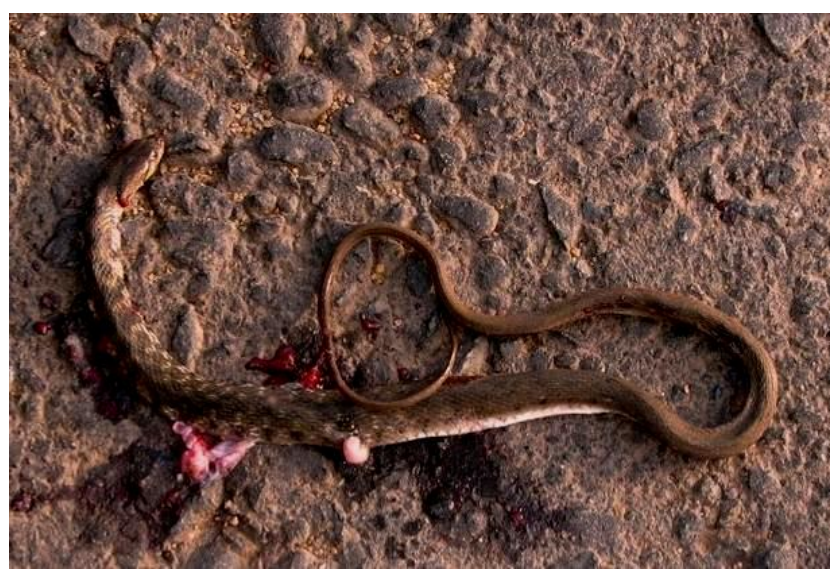

Figure 6: Xenochrophis cf. piscator

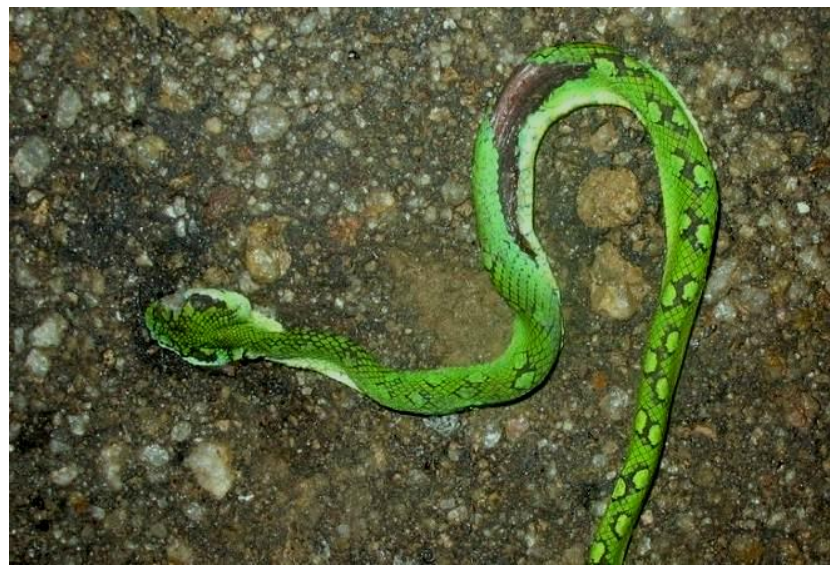

Figure 8: Trimeresurus trigonocephalus

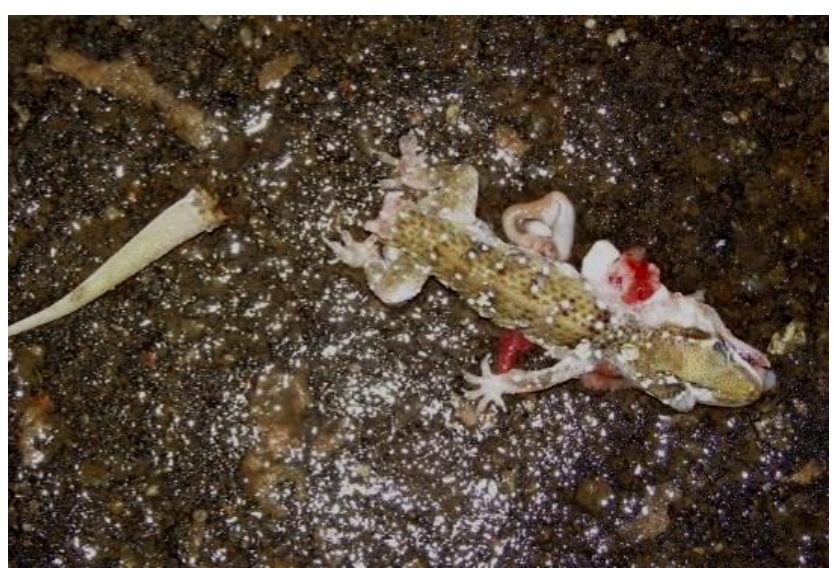

Figure 10: Hemidactylus lankae

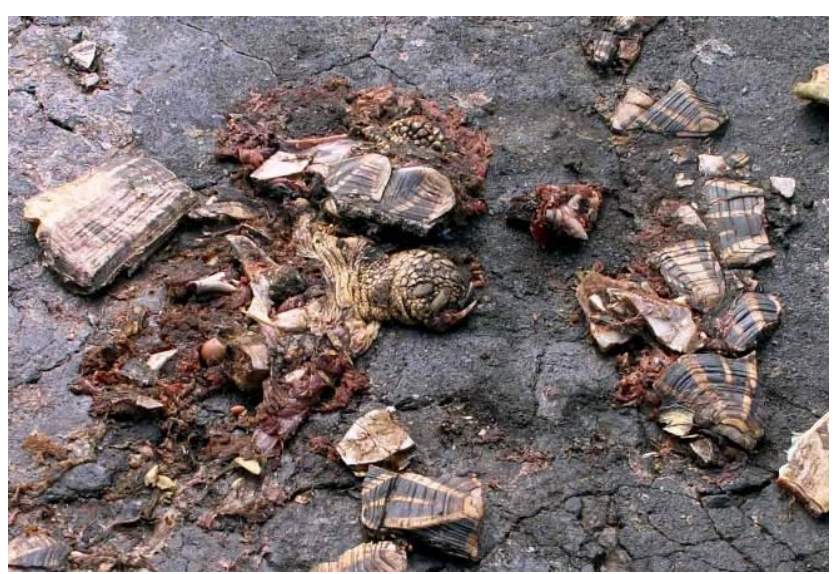

Figure 12: Geochelone elegans 


\section{PLATE 2}

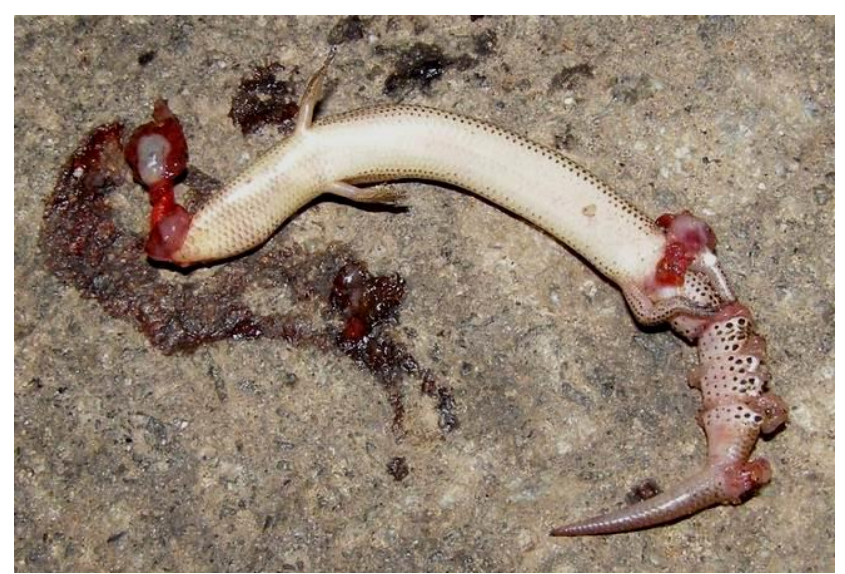

Figure 13: Lygosoma punctata

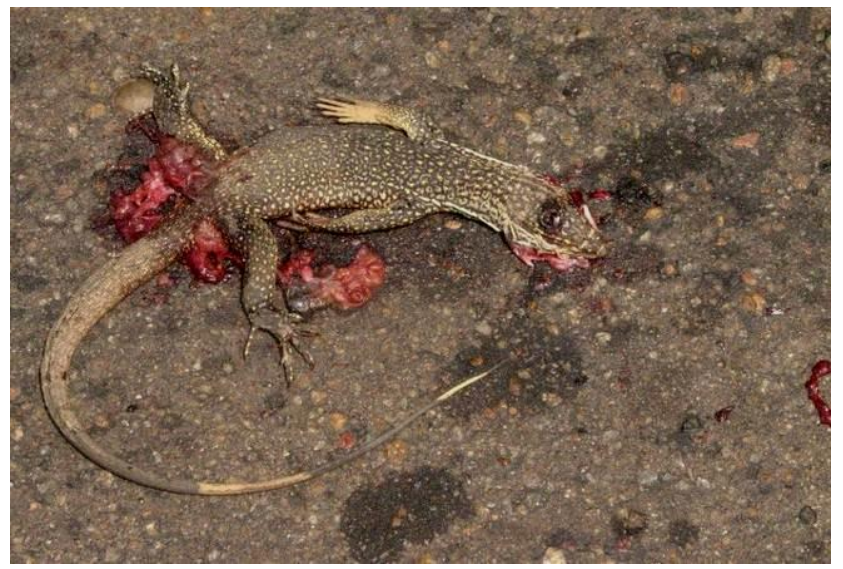

Figure 15: Varanus bengalensis

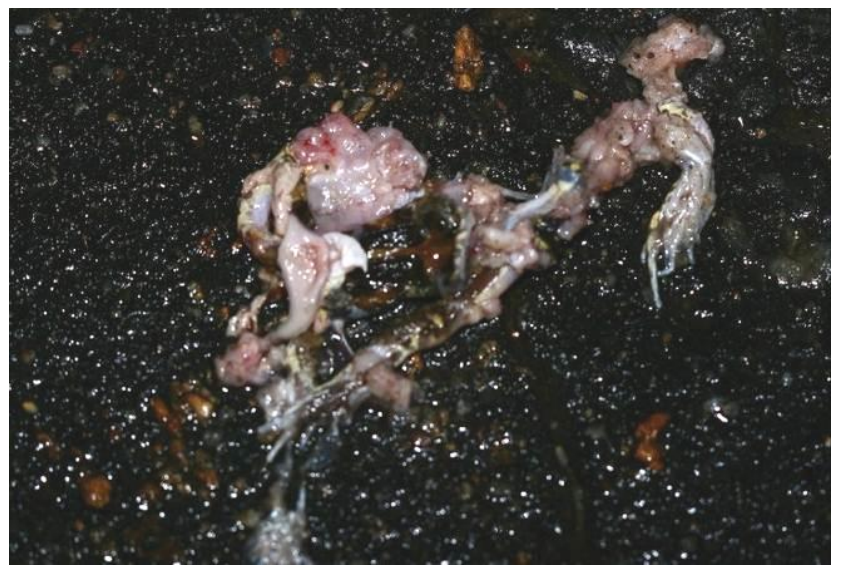

Figure 17: Kaloula taprobanica

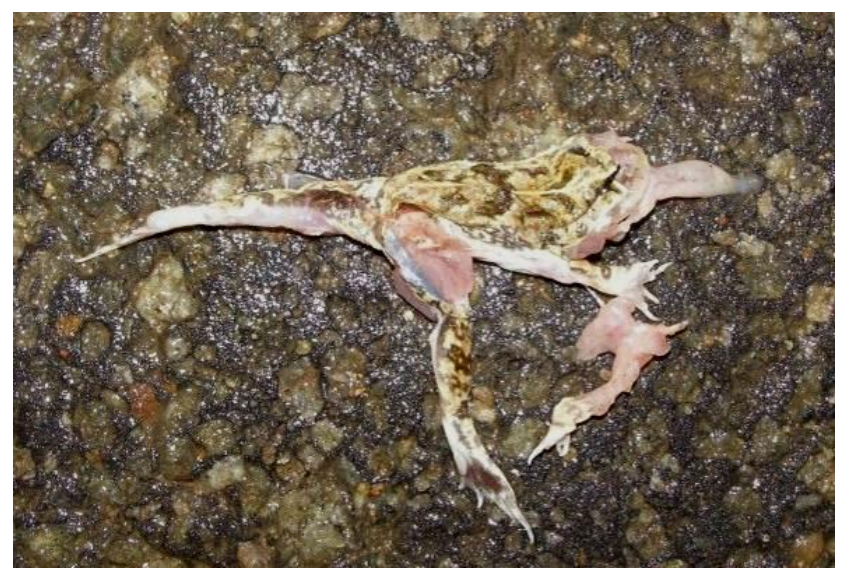

Figure 19: Sphaerotheca breviceps

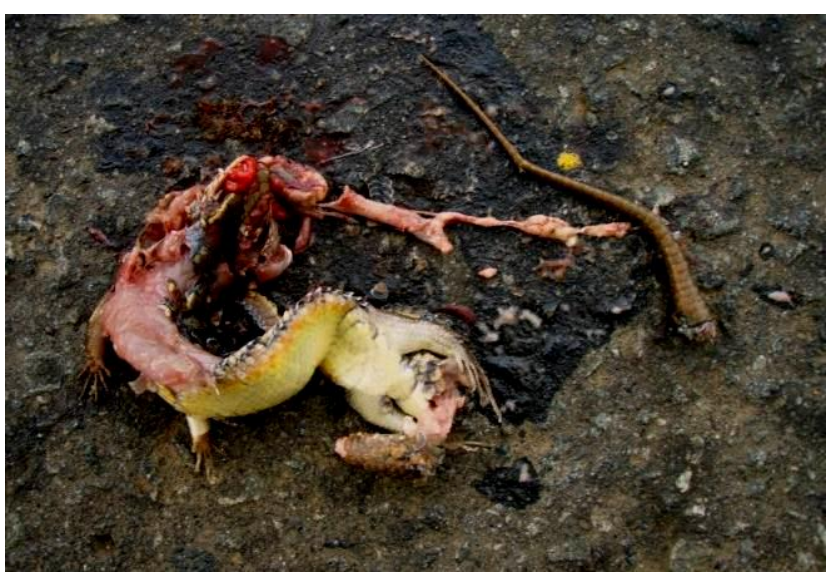

Figure 14: Eutropis carinata

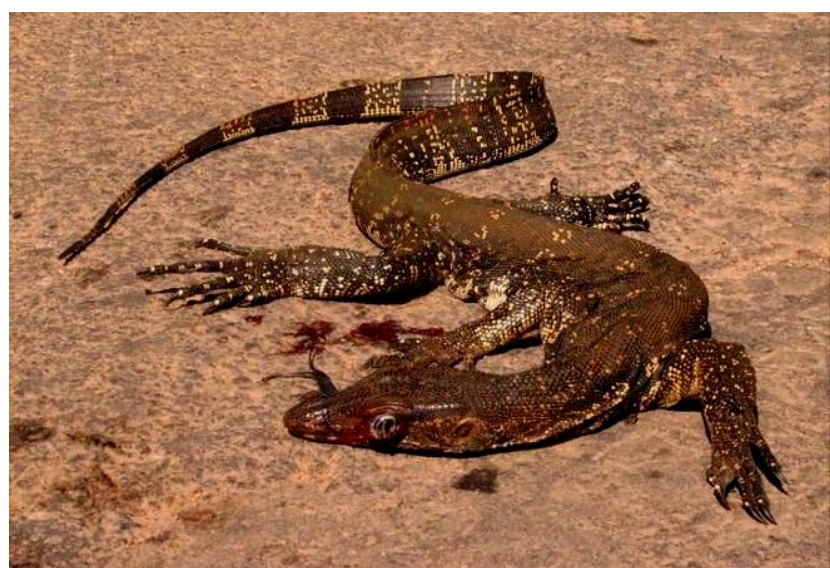

Figure 16: Varanus salvator

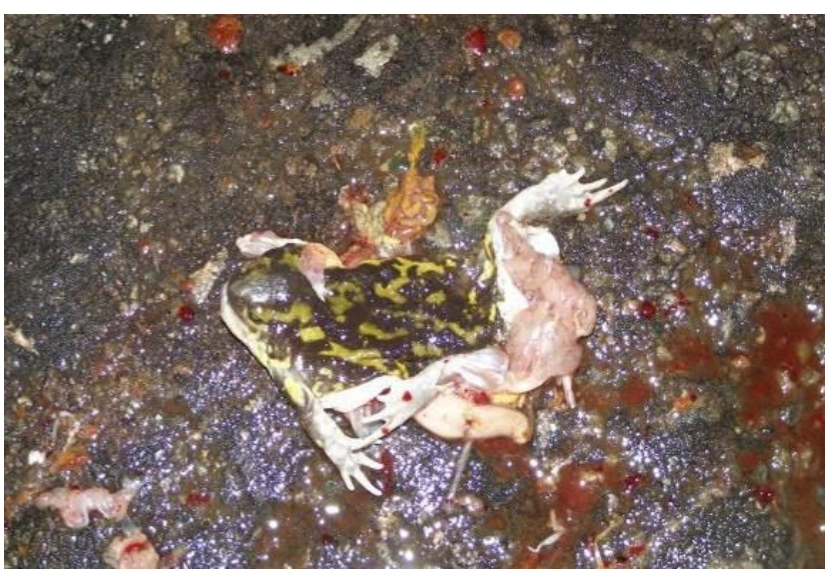

Figure 18: Uperodon systoma

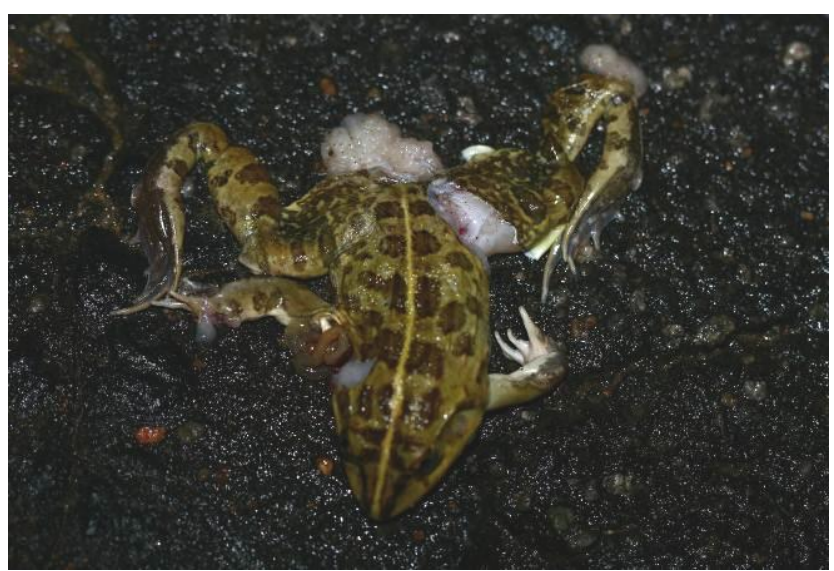

Figure 20: Hoplobatrachus crassus

TAPROBANICA VOL. 05: NO. 02 